\title{
A new species of Tmesiphantes (Araneae, Theraphosidae) from the state of Pará, Brazil
}

\author{
Hector M. O. Gonzalez-Filho, Antonio D. Brescovit \& Sylvia M. Lucas
} Laboratório Especial de Coleções Zoológicas, Instituto Butantan, Av. Vital Brazil, 1500, 05503-900, São Paulo, SP, Brazil. (gonzalezfilho@yahoo.com.br; adbresc@terra.com.br;
sylviamlucas@gmail.com)

\begin{abstract}
A new species of Tmesiphantes Simon, 1892, T. aridai sp. nov., is described and illustrated based on three males and three females collected at the Floresta Nacional do Tapajós, Santarém, state of Pará, Brazil. Males can be distinguished from T. perp Guadanucci \& Silva, 2012 by the palpal bulb with an inconspicous tegular basal projection, but presenting a very slender embolus with shorter keels not extending to the tip, and from T. nubilus Simon, 1892 by the tibial apophysis with two similarly sized branches, the prolateral one with a strong spine on the retrolateral margin. Females resemble T. nubilus by the aspect of the seminal receptacle but the constriction near the apex is less evident and apex shape is irregular. The new species represents the first record of Tmesiphantes from the Amazonian region, bringing the total number of species to eight.
\end{abstract}

KEYWORDS. Brazilian Amazon rainforest, Floresta Nacional do Tapajós, spider, taxonomy, Theraphosinae.

RESUMO. Uma nova espécie de Tmesiphantes (Araneae, Theraphosidae) do Estado do Pará, Brasil. Uma nova espécie de Tmesiphantes Simon, 1892, T. aridai sp. nov., é descrita e ilustrada baseada em três machos e três fêmeas coletadas na Floresta Nacional do Tapajós, Santarém, Estado do Pará, Brasil. Os machos distinguem se de T. perp Guadanucci \& Silva, 2012 pelo aspecto do palpo copulador com uma projeção tegular basal inconspícua, apresentando um êmbolo muito delgado, com quilhas mais curtas, não se estendendo até o ápice, e distinguem se de T. nubilus Simon, 1892 pela apófise tibial com dois ramos de tamanho semelhante, o prolateral com um forte espinho na margem retrolateral. As fêmeas se assemelham a T. nubilus pelo aspecto dos receptáculos seminais, porém com uma constrição menos evidente e formato do ápice irregular. A nova espécie representa o primeiro registro de Tmesiphantes para a região amazônica, elevando para oito o número de espécies conhecidas.

PALAVRAS-CHAVE. Região amazônica, Floresta Nacional do Tapajós, aranhas, taxonomia, Theraphosinae.

Tmesiphantes Simon, 1892 is a Neotropical genus of Theraphosinae, based on a couple of specimens of T. nubilus Simon, 1892 from the state of Bahia, Brazil, an Atlantic Forest domain. Males of Tmesiphantes can be recognized by the palpal bulb morphology, with conspicuous superior and inferior prolateral keels and long curved embolus, aspect of the tibial apophysis and by the metatarsus I, which bends to the retrolateral side of the retrolateral tibial apophysis, females can be distinguished by the spermathecae with two seminal receptacles, slightly constricted near the apex (PÉrez-Miles et al., 1996; Yамамото et al., 2007), except in T. hypogeus (see Bertani et al., 2013, figs D, E). The genus was revised by ҮАмамото et al. (2007) with description of three new species: T. amadoi, known by a male, $T$. caymmii, known by male and female and $T$. bethaniae known by a male, all from the state of Bahia. GuADANUCCI \& SiLVA (2012) described the first two species registered outside the Atlantic Forest domain, from the state of Minas Gerais, Brazil: T. perp known by male and a female and T. riopretano based only on a male. Recently, BERTANI et al. (2013) described T. hypogeus, based on two females collected in the Gruna da Parede Vermelha and Gruna das Cobras, also from Bahia.

During the identification of the mygalomorph spider's collection of the Faculdades Integradas do Tapajós, Santarém, Pará, Brazil, a new species of Tmesiphantes was identified. This new species, T. aridai sp. nov., comprises the first species recorded from the Brazilian Amazon rainforest, which is here described and illustrated.

\section{MATERIAL AND METHODS}

The material examined is deposited in the following institutions (abbreviation and curators in parentheses): Instituto Butantan, São Paulo (IBSP, A. D. Brescovit) and Faculdades Integradas do Tapajós, Santarém (FIT, H. M. Chalkidis). All measurements are in millimetres and were taken with a millimetric ocular lens. Total body length excludes chelicerae and spinnerets. Length of leg segments were measured between joints in dorsal view, length and width of carapace, eye tubercle, labium and sternum are maximum values obtained. Abbreviations: AME, anterior median eyes; ALE, anterior lateral eyes; PME, posterior median eyes; PLE, posterior lateral eyes; spines: ap, apical; d, dorsal; p, prolateral; r, retrolateral; v, ventral. Terminology: palpal bulb structures follows BERTANI (2000), number and disposition of spines, Petrunkevitch (1925) and types of urticating hairs, COOKE et al. (1972). Pictures were taken with a Leica DFC500 digital camera attached to a Leica MZ16A stereoscopic microscope. The spermathecae were dissected and cleared in lactic acid for internal structures observation and photographed in dorsal view. The left male palpal bulb was removed from the cymbium and photographed in dorsal, prolateral and retrolateral views. The left tibial spur was photographed in prolateral view, after having the setae removed for a 

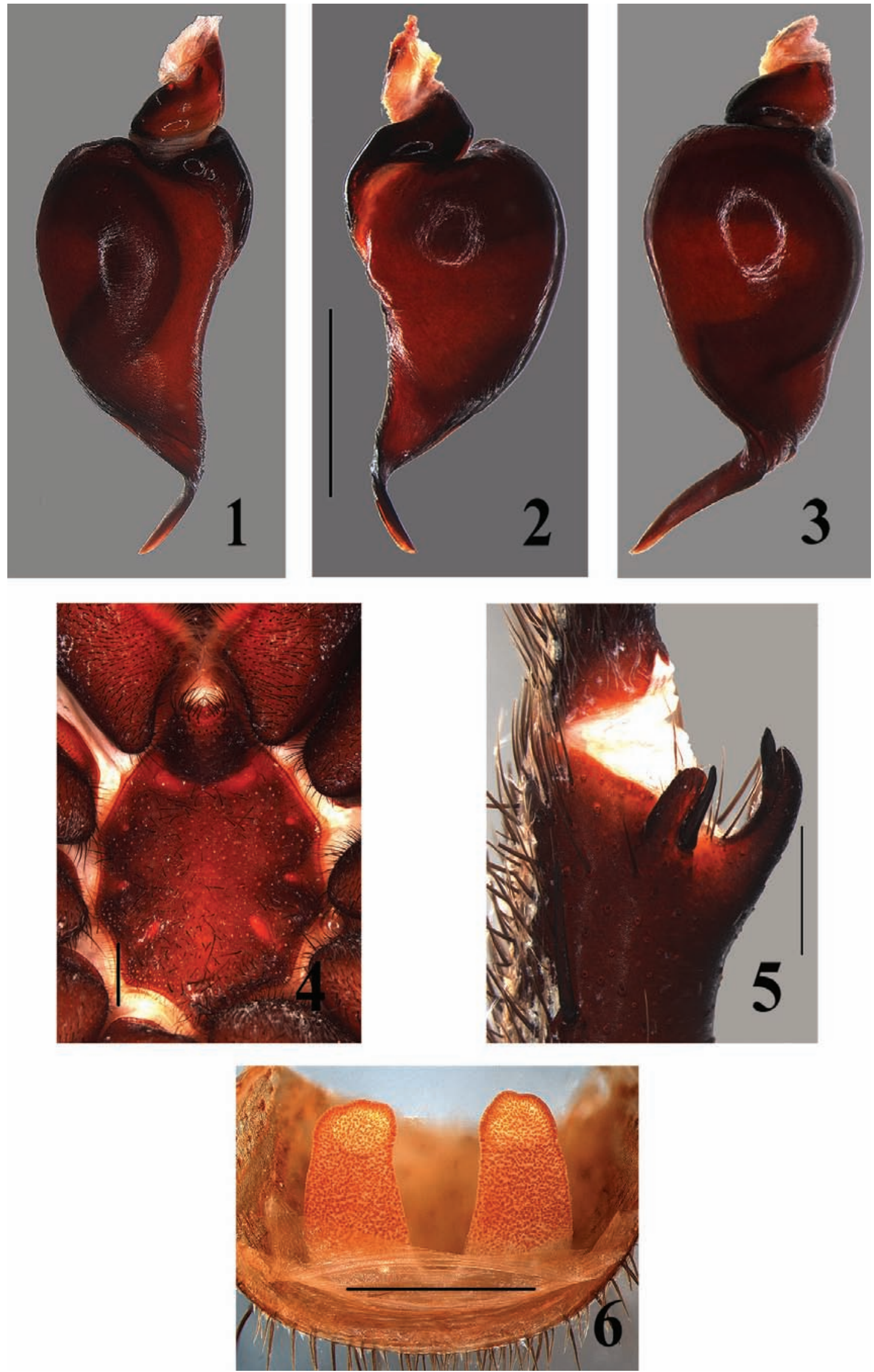

Figs 1-6. Tmesiphantes aridai sp. nov. 1-5, male holotype. 6, female paratype (IBSP 165019). 1-3, Left male palpal bulb: 1, prolateral view; 2, retrolateral view; 3 , dorsal view. 4, labium and sternum, ventral view. 5, left tibial apophysis, prolateral view. 6, spermathecae, dorsal view. Scale bars: $1 \mathrm{~mm}$. 
clearer view. The geographic coordinates were obtained using the program Google Earth and the distribution map was made using the program DIVA- GIS 7.5.

\section{RESULTS}

\section{Tmesiphantes aridai sp. nov.}

(Figs 1-9)

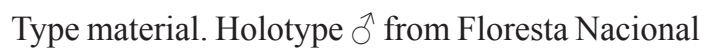

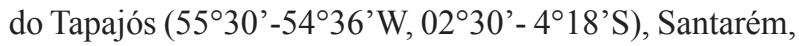
Pará, Brazil, X. 2011, A. D. Brescovit et al. leg. (IBSP
161737). Paratypes: $3 \hat{\jmath}$ (IBSP 161736, IBSP 165996, FIT 1036) and 3 ㅇ (IBSP 165019, IBSP 165020, FIT 1129), same data of holotype.

Etymology. The specific name is in honour of Felipe Arida, grandson of the last author.

Diagnosis. Males of Tmesiphantes aridai sp. nov. resemble T. perp (see GuADANUCCI \& SiLVA, 2012, figs 1113) and T. nubilus (see Yамамото et al., 2007, figs 3-5) by the morphology of the palpal bulb, but can be distinguished from T. perp by the palpal bulb with an inconspicuous tegular basal projection, but presenting a very slender embolus with shorter keels not extending to the tip (Figs
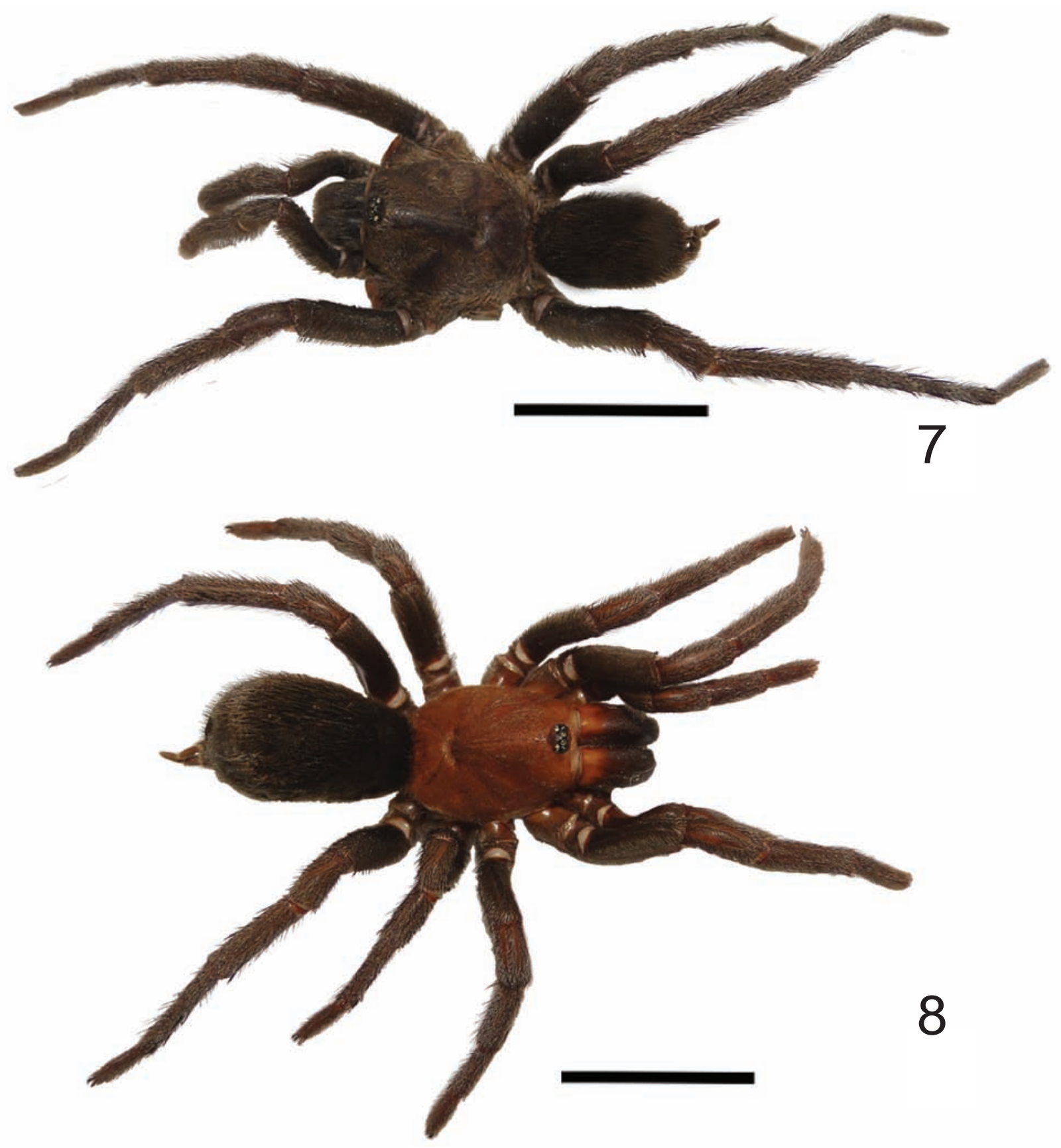

Figs 7-8. Tmesiphantes aridai sp. nov., habitus, dorsal view: 7, male holotype; 8, female paratype (IBSP165019). Scale bars: $1 \mathrm{~cm}$. Photos: Rafael P. Indicatti. 


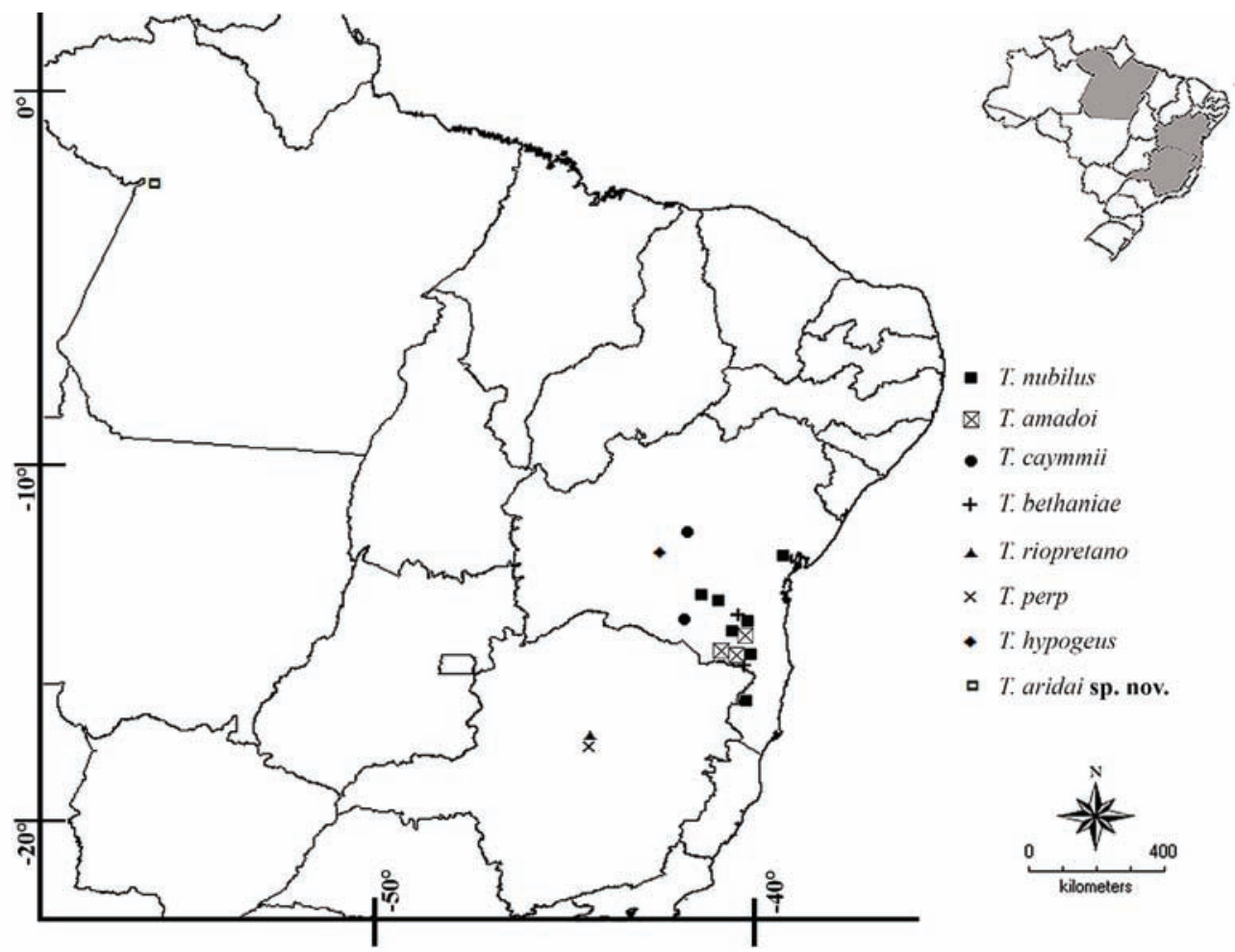

Fig. 9. Distribution map of the species of Tmesiphantes.

1-3), and from T. nubilus (sеe ҮАмамото et al., 2007, fig. 6) by the tibial apophysis with two similarly sized branches, the prolateral one with a strong spine on the retrolateral margin (Fig. 5). The females of the new species resemble T. nubilus due to the aspect of the seminal receptacles, but the constriction near the apex is less evident and apex shape is irregular (Fig. 6).

Description. Male (Holotype, IBSP 161737). Carapace, legs and abdomen dorsally dark brown (Fig. 7). Sternum, coxae and abdomen ventrally reddish brown (Fig. 4). Total length 22.5. Carapace 11.13 long, 9.13 wide, fovea procurved (Fig. 7). Clypeus narrow. Eye tubercle: 1.0 long, 1.63 wide. Eyes size and inter-distances: AME 0.33, ALE 0.45, PME 0.2, PLE 0.35, AME-AME 0.16, AME-ALE 0.1, PME-PME 0.7, PME-PLE 0.08, ALEPLE 0.1. Labium: 1.4 long, 1.7 wide, with 10 cuspules. Sternum: 4.55 long, 4.2 wide, oval (Fig. 4). Endites with $72 / 67$ cuspules (right/left). Basal segment of chelicerae with 14 teeth on prolateral margin. Palp: femur 5.63/ patella 3.5/tibia 4.88/cymbium 3.75/total 17.75. Legs: I: femur $8.66 /$ patella $3.88 /$ tibia $6.88 /$ metatarsus $6.63 /$ tarsus 4.0/total 30.0; II: 8.13/4.5/5.88/6.38/4.13/29.0; III : $7.5 / 3.66 / 5.13 / 7.5 / 3.88 / 27.63$; IV: 9.75/3.66/8.0/10.5/4.66/36.5. Spination: all tarsi without spines; palp: femur p0-0-1, patella p0-1, tibia p0-1-2ap; legs: I: femur p0-0-1-1ap, tibia v1r-0-1r-1-1r-1 p-1ap, metatarsus v0-2-0-0-1-2-0-1-1ap; II: femur p0-0-1, patella p0-1, tibia v0-2-0-0-1-1-0-0-3ap, p0-0-1-1-0-1, metatarsus v2-0-0-1-0-0-3ap; III: femur d0-0-1r, patella $\mathrm{d} 0-1$, tibia v0-1-1p-0-1-0-1r-0-3ap, metatarsus r0-2-0-1-0-1, v0-1p0-2-0-0-1d-3ap; IV: femur d0-0-1r, tibia v0-1-3-0-0-1r-
2-1-0-1 p-0-0-1r-0-3ap, metatarsus d0-2-0-0-0-1-0-1, v2$0-0-0-1-0-1-0-1-0-1 \mathrm{r}-4 \mathrm{ap}$. Tarsal scopulae: I undivided, II-IV divided by a longitudinal band with around 40 setae. Metatarsal scopulae: I-II on apical third, III restricted to apical fifth, IV with few apical setae. Metatarsus I slightly curved. Urticating hairs type III present. Palpal bulb with a slight curvature to the embolus, inconspicuous tegular basal projection, superior and inferior keels thin (Figs 1-3). Tibial apophysis with two strong branches of similar size, the retrolateral one large with an apical spine, the prolateral one with a spine situated basally on the retrolateral margin (Fig. 5).

Female (Paratype, IBSP 165019). Carapace yellowish-brown, legs and abdomen dorsally dark brown (Fig. 8). Sternum, coxae and abdomen ventrally as in male. Total length 20.63. Carapace 7.2 long, 6.9 wide, fovea procurved (Fig. 8). Clypeus narrow. Eye tubercle: 0.6 long, 1.38 wide. Eyes size and inter-distances: AME 0.43, ALE 0.48, PME 0.20, PLE 0.28, AME-AME 0.16, AMEALE 0.1, PME-PME 0.7, PME-PLE 0.08, ALE-PLE 0.1. Labium: 1.13 long, 1.73 wide, with 8 cuspules. Sternum: 3.97 long, 3.84 wide, as in male (Fig. 4). Endites with $62 / 67$ cuspules (right/left). Basal segment of chelicerae with 11 teeth on prolateral margin. Palp: femur 4.05/patella 2.8/tibia 3/cymbium 2.65/total 12.5. Legs: I: femur 5.3/ patella $3.4 /$ tibia $4.6 /$ metatarsus $3 /$ tarsus $2.15 /$ total 18.45 ; II: 4.6/3.2/3.65/2.9/2.25/16.6; III: 5.1/3.05/2.25/3.35/1.75/15.5; IV: 5.6/3.65/5.25/6.25/3.1/23.85. Spination: all tarsi without spines; palp: femur d0-0-1, tibia 0-2ap; legs: I: femur d00-1, metatarsus v0-1-0-0-2ap; II: femur d0-0-1, tibia v0-1, metatarsus v0-1-0-0-3ap, d0-1-0; III: femur d0-0-1, patella 
p0-1, tibia v0-1-0, p0-1-1-1-0-2ap, r0-1-0-1, metatarsus v0-0-3-1p-0-4ap; IV: femur d0-0-1, patella p0-1, tibia v0-0-1r -1p-0-2ap, metatarsus v1r-0-1r-2-0-1-1-0-1p-01d-4ap. Tarsal scopulae: I-IV divided by a longitudinal band of setae as in male. Metatarsal scopulae: I-II 1/3 apical, III restricted to apical fifth, IV with few apical setae. Urticating hairs type IV present. Spermathecae formed by two receptacula with little constriction near apex (Fig. 6).

Variation. Males $(n=4)$ : total length: 18.37-22.5. Labium with 7-13 cuspules. Female $(n=3)$ : total length: 17.13-20.63. Labium with 6-13 cuspules.

Distribution. Known only from the type locality (Fig. 9).

Acknowledgements. We wish to thank Dr. Hipócrates Chalkidis for the donation of the specimens, to Rafael P. Indicatti for assistance in illustrations, also to Ray Gabriel for helpful comments and corrections on this manuscript. This work was supported by FAPESP (2011/50689-0), INCTTox PROGRAM of CNPq (Conselho Nacional de Desenvolvimento Científico e Tecnológico) to ADB and PAP program to HGF.

\section{REFERENCES}

Bertani, R. 2000. Male palpal bulbs and homologous features in Theraphosinae (Araneae, Theraphosidae). Journal of Arachnology 28:29-42.

Bertani, R.; Bichuette, M. E. \& Pedroso, D. R. 2013. Tmesiphantes hypogeus sp. nov. (Araneae, Theraphosidae), the first troglobitic tarantula from Brazil. Anais da Academia Brasileira de Ciências 85:235-243.

Cooke, J. A. L.; Roth, V. D. \& Miller, F. R. 1972. The urticating hairs of theraphosid spiders. American Museum Novitates 2498:1-43.

Guadanucci, J. P. L \& Silva, W. F. 2012. Two new species of Tmesiphantes Simon (Araneae, Mygalomorphae, Theraphosidae) from the state of Minas Gerais, Brazil. Studies on Neotropical Fauna and Environment 47:139-145.

Pérez-Miles, F.; Lucas, S. M.; Silva Jr, P. I. \& Bertani, R. 1996. Systematic revision and cladistic analysis of Theraphosidae (Araneae, Theraphosidae). Mygalomorph 1:33-68.

Petrunkevitch, A. 1925. Arachnida from Panama. Transactions of the Connecticut Academy of Arts and Sciences 27:51-248.

Yamamoto, F. U.; Lucas, S. L.; Guadanucci, J. P. L \& Indicatti, R. P. 2007. Revision of the genus Tmesiphantes Simon (Araneae, Mygalomorphae, Theraphosidae). Revista Brasileira de Zoologia 24:971-980. 